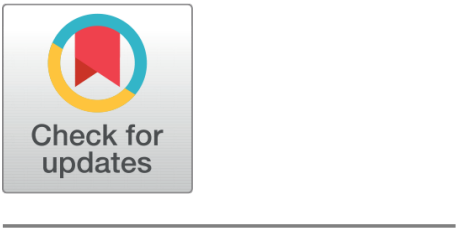

OPEN ACCESS

Received: 10.07.2021

Accepted: 04.08.2021

Published: 18.08 .2021

Citation: Tripathi S, Pandey R, Singh A, Mishra S (2021) Isolation and Characterisation of Value Added Product from Underutilised Part of Banana. Indian Journal of Science and Technology 14(28): 2317-2326. https://doi.org/

10.17485/IJST/v14i28.1284

* Corresponding author.

foodnutritionsm27.bbau@gmail sunitabbau@gmail.com.com

Funding: None

Competing Interests: None

Copyright: ( 2021 Tripathi et al. This is an open access article distributed under the terms of the Creative Commons Attribution License, which permits unrestricted use, distribution, and reproduction in any medium, provided the original author and source are credited.

Published By Indian Society for Education and Environment (iSee)

ISSN

Print: 0974-6846

Electronic: 0974-5645

\section{Isolation and Characterisation of Value Added Product from Underutilised Part of Banana}

\author{
Srishti Tripathi ${ }^{1}$, Rashmi Pandey ${ }^{1}$, Amardeep Singh ${ }^{1}$, Sunita Mishra ${ }^{2 *}$ \\ 1 MSc Food Science and Technology, Babasaheb Bhimrao Ambedkar University, Lucknow \\ (U.P), India \\ 2 Dean and HOD, Food Science and Technology Department, Babasaheb Bhimrao Ambedkar \\ University, Lucknow (U.P), India
}

\section{Abstract}

Objectives: To extract value added product (pectin) from banana peel, its optimisation by Response Surface Methodology and its characterisation. Method/Analysis: This study is carried out for the isolation of pectin from banana peel by using the acid extraction method, its optimization was done by using a software of design expert, version 8.0 based on three factorsTime, Ph, and Temperature. On the basis of three factors yield of a pectin was calculated and find out the optimum condition of pectin extraction. Hence, its characterization based on its equivalent weight, methoxyl content, anhydrouronic acid, degree of esterification, moisture content and ash content were also analysed to know the nature of a pectin. Findings: The most suitable condition for pectin extraction was $\left(\mathrm{pH}-2.5\right.$, Temperature- $90^{\circ} \mathrm{C}$, Time2.5 hours) by using $0.5 \mathrm{~N}$ of hydrochloric acid where the pectin yield was highest obtained i.e., 23-24\%. For optimization, the Central Composite Design of RSM was performed at different parameters. RSM was used to optimize the pectin at different time $(1,2,3,4$ hours $)$, temperature $\left(60,70,80\right.$ and $\left.90^{\circ} \mathrm{C}\right)$ and $\mathrm{pH}(1.5,2.5,3.5$ and 4.5$)$ respectively. Under optimum conditions, the pectin was characterized based on their equivalent weight, methoxyl content, ash content, moisture content, degree of esterification, anhydrouronic acid. Novelity: The novelty of this study is that the pectin has been extracted with a yield of 23$24 \%$.As compared to other studies, the pectin was characterized based on their equivalent weight, methoxyl content, ash content, moisture content, degree of esterification, anhydrouronic acid where it was found to be $1428.57 \mathrm{~g} / \mathrm{ml}, 9.3 \%$, $4.57 \%, 12.42 \%, 62 \%, 31.68 \%$ respectively. A few studies have been done about the optimisation of a pectin from banana peel.

Keywords: By-product utilization; Anhydrouronic acid; Methoxyl content; Isolation; Value added; Optimization 


\section{HIGHLIGHTS}

- Proper by-product utilization of resources available in abundance in the country of study (India).

- Protecting the environment by proper waste management.

- Recognizing pectin as a value-added product.

- Standardization of extraction process of pectin from banana peel.

- Potential uses of pectin in the food Industry.

\section{Introduction}

India ranks second in the world production of fruits and vegetables and is the second-largest banana producer i.e, $25 \mathrm{MT}$ (FAO). A large amount of fruits and vegetables by-products get wasted by food-producing industry which will further cause a problem to the environment and from the environment to the human hence it is a challenging task for all the food technologists to get rid of this problem by utilizing a by-product and underutilised part of fruits and vegetables i.e, its peel, stem, seed, etc. According to compiled data in a new report by Emerson Climate Technologies India, 18\% of India's fruits and vegetable production valued at 13,300 crores is wasted annually. There are many beneficial substances present in by product of fruits and vegetables.

Banana is an important tropical fruit all over the world. Production of banana is around 102028.17 thousand tons globally out of which India accounts for 29.19\% in which Tamil Nadu, Maharastra, Gujarat, Karnataka are the leading states (APEDA). Although the fruit is mostly consumed fresh but also can be processed into different types of products in small-scale industries, that includes chips, smoothies, ice cream, dried fruits, bread, flour, its also used as an ingredient for functional foods ${ }^{(1)}$. Nowadays banana peel being considered waste is discarded into landfills without using its potential materials present in it ${ }^{(2)}$. Banana peels are a pectin-rich material (ranging from $15.89 \%$ to $24.08 \%$ ) depending on the type and variety of bananas ${ }^{(3)} .40 \%$ weight of fresh banana fruit is banana peel ${ }^{(4)}$. Pectin is found in the cell wall and middle lamellae of all plants and is a high molecular weight carbohydrate polymer. It is an amorphous and colloidal polysaccharide, which is the backbone of $\alpha(1,4)$ galacturonic acid ${ }^{(5)}$. Pectin is a Greek word that comes from PEKTOS which means firm and hard. Pectin can form a gel under a certain temperature, its gelling properties mostly depend on the "Degree of methylation". Generally, pectin is classified into three groups- i) Pectin more than $75 \%$ of methylation, ii) Pectin less than $75 \%$ of methylation, and, iii) Pectin without methyl of esterification ${ }^{(6)}$

Nowadays, many researchers concerning about the extraction methods, their optimization, and characterization. The galacturonic acid content in pectin must be $65 \%$ according to FAO, methanol is used to esterify the effect of galacturonic acid residues. Pectin is a valuable by-product, to be utilized as a value-added product through adopting relevant methods. It has many applications in the food and dairy industries, as it is widely used in bakery and confectionery products, such as jams, jellies, marmalades, and in the dairy industry, used in yogurt, to stabilize milk drinks. It is also used as emulsifiers, gelling agents, thickening agents, etc ${ }^{(7)}$. Pectin contains a high amount of fiber and very less amount fat and cholesterol that's why it helps in the dietary supplements Industry. Pectin is also known as a "Vegan Product". As the coronavirus disease (covid 19) spread all over the world, the demand and consumption of functional and nutritional food products have been increased. As a result, the demand for pectin also increases in dairy products and fruit beverages. According to the IMARC (International Market Analysis Research and Consulting Group), Europe represents the largest market of pectin followed by Germany, Japan, and China. According to CAGR (Compound annual growth rate), the demand for pectin in India is expected to exceed 8-12\%. So, a suitable method has to be adopted to utilize the peel of the banana and turn the problem into a solution

Many research has been studied by several authors about the extraction method ${ }^{(8)}$, its characterization, and the factors affecting the yield of pectin. ${ }^{(4)}$ had extracted pectin from saba banana peel and found that at 4 hours the outcome of pectin was $13.5 \%$ only, while at 1,2 , and 3 hours it was $7.5 \%, 10.5 \%$, and $12 \%$ respectively ${ }^{(9)}$ resulted that pectin yield from ripe bananas was $11.87 \%$ whereas $16.54 \%$ from unripe banana. ${ }^{(3)}$ compared five varieties of banana out of which KluaiLeb Mu Nang variety contain a high amount of pectin yield i.e., $24.08 \%$ among all.

This work is therefore intended at extracting and assessing pectin from the banana peel in aspects of its optimization and characterization. The main objectives of this research were: $a$ ) To isolate the pectin from the peel of a banana, $b$ ) To investigate various factors such as $\mathrm{pH}$, temperature, time that affect the yield of pectin c) To determine the standard optimum condition for pectin extraction by its optimization (RSM), d) To characterize pectin based on various parameters such as equivalent weight, anhydrouronic acid, methoxyl content, moisture content, ash content, degree of esterification, etc. 


\section{Material and Method}

\subsection{Material}

The experiment was carried out at the laboratory of food and nutrition, Babasaheb Bhimrao Ambedkar University Lucknow. The banana peels taken for research were purchased from the local market of the south city Lucknow. All the chemicals, glassware, and equipment used for the isolation and optimization of pectin are of analytical grade. All the glassware used in a laboratory was sterilized properly and proper safety rules were also followed.

\subsection{Methods}

\subsubsection{Pre-treatment of banana peel}

The banana peel was cleaned and washed under running tap water. It was weighed $500 \mathrm{gm}$ for each treatment and blended. Peels were separated based on their type and cut into slices to increase the surface area for a faster drying rate. It was then soaked in $0.5 \%$ metabisulphite solution for an hour to prevent discoloration and browning of peels, peels were placed in a hot air oven at $65^{\circ} \mathrm{C}$ for 24 hours followed by cooling at room temperature. Followed by grinding of dried peels in an 80 meshes sieve size and put in an airtight glass container.

\subsubsection{Chemicals used for isolation}

$0.5 \mathrm{~N} \mathrm{HCl}$, Ethanol (Absolute), Distilled water

\subsubsection{Pectin Isolation from banana peel}

Pectin was isolated based on the best optimization result obtained by using Response Surface Methodology. $40 \mathrm{gm}$ of homogenized banana peel was taken in $500 \mathrm{ml}$ of a previously sterilized beaker, add $500 \mathrm{ml}$ of distilled water $(1: 10)^{(3)}$. To this mixture, add $21 \mathrm{ml}$ of $0.5 \mathrm{~N}$ Hydrochloric acid ( $\mathrm{pH} 2.5$ ). Continuously stir the mixture for 2.5 hours at $90^{\circ} \mathrm{C}$ with the help of a glass rod in a hot plate. The suspension is then allowed to cool down at normal room temperature and is filtered through a muslin cloth ( $1 \mathrm{~mm}$ mesh size). To the filtrate, add the same amount of ethanol (absolute) and left overnight for precipitation of pectin. The next day, discard the supernatant and centrifuge at $5000 \mathrm{rpm}$ for $15 \mathrm{~min}$ at temperature $5^{\circ} \mathrm{C}$ to obtained pectin. The flocculant was then skimmed off and the resulted pectin was dehydrated using a hot air oven to achieve a constant weight. A sealed container is used to store dried pectin to prevent moisture absorption. Figure 1 shows a schematic diagram of pectin isolation from the banana peel ${ }^{(9)}$. The pectin yield can be calculated using the following expression:

$$
\text { Pectin yield }(\%)=\text { Final weight }- \text { Initial weight } \times 100 \div \text { sample weight }
$$

\subsection{Pectin Characterization}

The isolated pectin obtained from the peel of the banana undergo the following characteristics quantitatively:

a) Moisture content b) Ash content c) Amide content d) Equivalent content e) Methoxyl Content f) Total Anhydrouronic acid content g) Degree of Esterification

\subsubsection{Moisture content}

According to Ranganna's method ${ }^{(10)}$, the Moisture content of pectin can be determined by taking 1 gram of sample in a previously sterilized Petri plate, weighed it in an electronic weighing balance, place them in hot air oven for about 4-5 hours at $80^{\circ} \mathrm{C}$. Cool it in a desiccator for 15 minutes to absorb extra moisture and then the final reading of a Petri plate was taken.

Moisture content can be calculated by using the following formula:

$$
\text { Moisture content }(\%)=\text { Weight of residue } \times 100 \div \text { Weight of pectin }
$$

note-The sample was not used for further evaluation as the pectin gets degraded after exposure to the atmosphere.

\subsubsection{Ash content}

One of the pectin important characteristics is its Ash content from the gel formation point of view. In this method, 2 grams of sample were weighed in a crucible by using an electronic weighing balance. The sample was ignited on the hot plate at $100^{\circ} \mathrm{C}$ for 15-20 minutes until the fumes get stopped evaporating (charring). Crucible is then placed in a muffle furnace for about 3 hours at a very high temperature i.e, $520^{\circ} \mathrm{C}$. Cool the crucible in a desiccator to absorb extra moisture and weighed it ${ }^{(4)}$ 


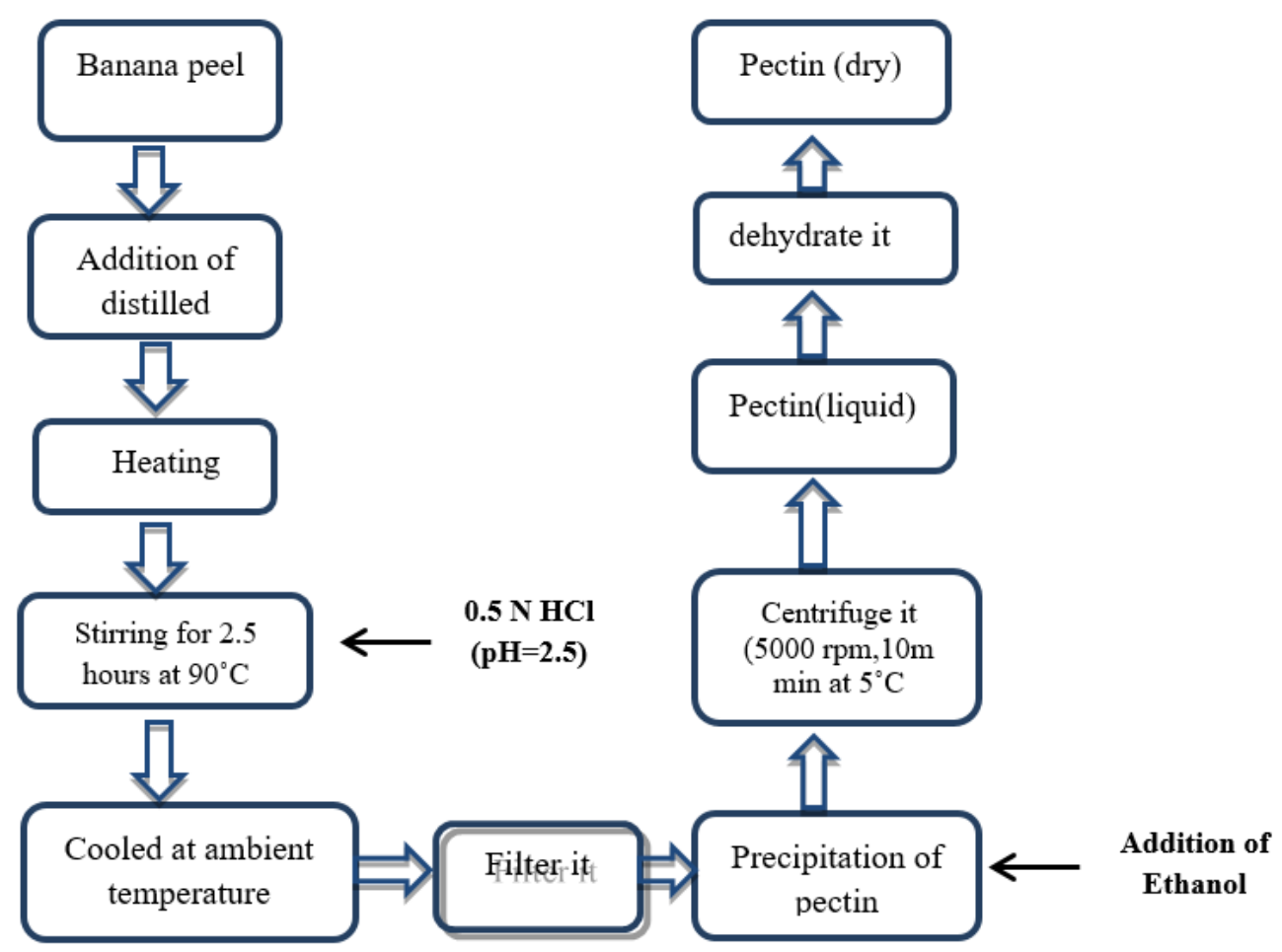

Fig 1. Steps for Isolation of pectin from banana peel

The formula for ash content was determined by Ranganna:

$$
\text { Ash content }(\%)=\text { weight of ash } \times 100 \div \text { weight of pectin }
$$

\subsubsection{Determination of amide content}

According to Pratik.B.Kamble ${ }^{(4)}, 0.1$ gram of the pectin sample was placed in a test tube, and $5 \mathrm{ml}$ of sodium hydroxide was added to it. Few drops of hydrochloric acid were then added. Let it stand for few minutes for precipitation. If the mixture gets precipitated indicated the presence of amide in it. The reaction involved in this solution are as follows:

$$
\begin{aligned}
& \mathrm{CH} 3 \mathrm{CONH} 2+\mathrm{NaOH} \rightarrow \mathrm{CH} 3 \mathrm{COONA}+\mathrm{NH} 2 \\
& \mathrm{CH} 3 \mathrm{COONa}+\mathrm{HCL} \rightarrow \mathrm{CH} 3 \mathrm{COOH}+\mathrm{NaOH}
\end{aligned}
$$

\subsubsection{Equivalent weight determination}

Pectin's equivalent weight is likely to depend on the free acid present in pectin. A small amount of equivalent weight indicated the degradation of pectin. Equivalent weight can be measured using the Ranganna method. Take $0.5 \mathrm{~g}$ of the pectin sample into $250 \mathrm{ml}$ of the Erlenmeyer flask, and add $50 \mathrm{ml}$ of $90 \%$ ethanol. Then add 1 gram of sodium chloride followed by $100 \mathrm{ml}$ of distilled water. Next, add 6-7 drops of phenol red indicator, titrate with $0.1 \mathrm{~N}$ sodium hydroxide solution until light pink continues for 30 seconds. Equivalent weight can be measured by using the following equation:

$$
\text { Equivalent weight }=\text { weight of pectin } \times 100 \div \text { titre value of alkali } \times \text { normality of alkali }
$$

\subsubsection{Determination of methoxyl content}

The methoxyl content of pectin is also considered to be an important factor because it determines the setting of the pectin and its gelling ability. Here, the above neutral solution is then collected to determine the methoxyl content. Add, $25 \mathrm{ml}$ of 0.25 $\mathrm{N}$ sodium hydroxide. The mixture should be stirred and kept at room temperature for 30 minutes. Then add $25 \mathrm{ml}$ of $0.25 \mathrm{~N}$ 
hydrochloric acid and titrate with $0.1 \mathrm{~N}$ sodium hydroxide until a light pink color appears. The calculation formula of methoxyl content is as follows:

$$
\text { Methoxyl content }(\%)=\text { ml of Alkali } \times \text { Normality of alkali } \times 3.1 \div \text { weight of the sample }
$$

\subsubsection{Total anhydrouronic acid}

Determining the methoxyl content of pectin and the equivalent weight of pectin, total anhydrouronic acid content can be determined. This is an important characteristic in determining the purity of pectin. The molecular formula of total anhydrouronic acid is :

$$
A U A(\%)=(176 \times 0.1 z \times 100 \div w \times 1000)+(176 \times 0.1 y \times 100 \div w \times 1000)
$$

The molecular weight of $\mathrm{AUA}=176 \mathrm{gm}$

$\mathrm{W}=$ Sample weight

$\mathrm{Z}=$ Titre value of sodium hydroxide from equivalent weight determination

$\mathrm{Y}=$ Titre value of sodium hydroxide from methoxyl content determination ${ }^{(11)}$

\subsubsection{Degree of Esterification}

It can be determined by the percentage of methoxyl group content and the percentage of anhydrouronic acid content. This is considered to be an important parameter in determining the functional properties of pectin ${ }^{(9)}$. Formula to determine the degree of esterification is-

$$
D E(\%)=176 \times \text { percentage of methoxyl content } \times 100 \div 31 \times \text { percentage of anhydrouronic acid }
$$

\subsection{OPTIMISATION OF PECTIN}

Optimization is very important to obtain the best pectin yield. Pectin yield is usually affected by three factors. That is temperature, time, and $\mathrm{pH}$. The range of variables was selected based on the literature ${ }^{(12)}$. Using design expert software to achieve optimized conditions for pectin extraction from peels, the predicted values of the design conditions are $90^{\circ} \mathrm{C}$ (temperature), 2.5 hours (time), and $\mathrm{pH} 2.5$, and the optimal pectin value ranges are obtained respectively (20\% to $24.0 \%$ ). Compared to data obtained in the literature, the pectin yield was within the acceptable range of the banana peel extraction conditions. Therefore, this study indicates that banana peel is a quite rich source of pectin. All experiments are conducted randomly to minimize errors. All 20 experiments were performed, and the data were analyzed statistically by expert design software 8.0 to find the yield of pectin. Based on these variables, the yield of Pectin was calculated. The importance of the results is established by analysis of variance (ANOVA). Select variables based on the literature ${ }^{(6)}$. The experimental value and the predicted value are compared to verify the model, and the error between the two values is less than 5 indicating a good result ${ }^{(13)}$. The variables are coded as extraction time $\left(\mathrm{X}_{1}\right)$, temperature $\left(\mathrm{X}_{2}\right), \mathrm{pH}\left(\mathrm{X}_{3}\right)$. The variables have been standardized and coded as levels $(-1$ to +1$)$, and their actual values are shown in Table 1 :

Table 1. Coded level of three variables and their actual values

\begin{tabular}{llllllll}
\hline Extraction parameters & Units & Code & Levels & & & \\
\hline & & & $-\alpha$ & -1 & 0 & $+\alpha$ & +1 \\
\hline Time & Hour & $\mathrm{X}_{1}$ & -0.02 & 1 & 2.55 & 4 & 5.022 \\
Temperature & ${ }^{\circ} \mathrm{C}$ & $\mathrm{X}_{2}$ & 49.77 & 60 & 76.50 & 90 & 100.2 \\
$\mathrm{pH}$ & & $\mathrm{X}_{3}$ & 0.818 & 1.5 & 2.37 & 3.5 & 4.181 \\
\hline
\end{tabular}

\section{RESULT AND DISCUSSIONS}

\subsection{Percentage yield}

Pectin was extracted at optimum condition $\left(90^{\circ} \mathrm{C}, \mathrm{pH}-2.5,2.5\right.$ hour $)$. The percentage yield of the pectin extracted from the peel powder by using $0.5 \mathrm{~N} \mathrm{HCl}$ at $\mathrm{pH} 2.5$ ranges from $20 \%-23.43 \%$. The yield of pectin was higher by using hydrochloric acid as compared to other acids due to the higher ionic strength of $\mathrm{HCl}^{(9)}$. Unripe banana has more yield as compared to ripe due to the degradation of pectin enzymes such as pectin acid lyase and pectin methyl ester hydrolase ${ }^{(14)}$. According to my study, at 
2.5-hour yield of pectin, was between $20-23 \%$ it decreases as time increases due to the breakdown of pectin bonds. Thus, 2.5 hours was considered as the optimum time for pectin extraction which gives a higher yield of pectin. Other researchers found that yield of pectin lies between 13-13.5\% from ripe banana and $16.54 \%$ from unripe banana at 4 hours ${ }^{(9)}$.

\subsection{Effect of extraction process variables}

\subsubsection{Effect of Temperature on pectin Extraction}

Figure 2(a) demonstrates that temperature affects the yield of pectin. As the temperature rises, the yield of pectin also increases. At $90^{\circ} \mathrm{C}$ pectin gives a higher yield but after $90^{\circ} \mathrm{C}$ yield of pectin will get decreases due to the breakdown of pectin molecules made up of $\alpha(1,4)$ galacturonic acid. Thus, high temperature also increases the extraction process cost in industries and the process will no more cost-effective. While the previous study by ${ }^{(15)}$ stated that pectin yield decreases after reaching the temperature of $76^{\circ} \mathrm{C}$ and Ermias Girma stated that the yield of pectin is higher between $80-82^{\circ} \mathrm{C}$ As the temperature rises further from $82^{\circ} \mathrm{C}$ to $89^{\circ} \mathrm{C}$, the pectin yield of the banana peel tends to decrease.

\subsubsection{Effect of $\mathrm{pH}$ on Pectin yield}

According to Figure 2(b), the yield of pectin decreases as the $\mathrm{pH}$ increases. At $\mathrm{pH} 2.5$, pectin offers the highest yields. A previous study of ${ }^{(6)}$ found similar results. He said that the pectin yield decreases with increasing $\mathrm{pH}$, as some pectin is connected to the components of the cell wall, but the pectin molecule isnot degraded in a weakly acidic solution and is partially solubilize from the plant tissue.

\subsubsection{Effect of time on Pectin Extraction}

Figure 2(c) shows the increase in the quantity of pectin by lengthening the time. The yield of pectin rises to 2.5 hours, after that pectin yield gradually decreases, causing the thermal degradation effect on pectin yield. Also, the color of pectin is dark brown. Previous studies of ${ }^{(6)}$ have demonstrated that the yield of pectin is maximal at 120 minutes. But after that, the yield decreases over time. He said that the extraction step increases the pectin concentration in the solution, so that the extraction rate is further lowered due to the reduction of concentration gradient, and the second solution becomes more viscous. On the other hand, ${ }^{(15)}$ explains that the extraction time varies with the solid-liquid ratio (S:L). With low SLR, pectin yield increases with time of extraction, while pectin yield decreases overtime with high SLR.

Table 2. Anova table for a quadratic model of response surface

\begin{tabular}{llllll}
\hline SOURCE & Sum of squares & $\mathrm{df}$ & Mean Squares & F value & P-value \\
\hline Model & 14.09 & 9 & 1.57 & 25.99 & 0.0001 \\
$\mathrm{X}_{1}$ & $6.47 \times 10^{3}$ & 1 & $6.47 \times 10^{3}$ & 0.11 & 0.7498 \\
$\mathrm{X}_{2}$ & 2.45 & 1 & 2.45 & 40.63 & 0.0001 \\
$\mathrm{X}_{1} \mathrm{X}_{2}$ & 1.78 & 1 & 1.78 & 29.52 & 0.0003 \\
$\mathrm{X}_{1} \mathrm{X}_{3}$ & 0.084 & 1 & 0.084 & 1.39 & 0.2655 \\
$\mathrm{X}_{2} \mathrm{X}_{3}$ & 0.29 & 1 & 0.29 & 4.74 & 0.0544 \\
$\mathrm{X}_{12}$ & 3.17 & 1 & 3.17 & 52.62 & 0.0001 \\
$\mathrm{X}_{22}$ & 0.18 & 1 & 0.18 & 3.00 & 0.1137 \\
$\mathrm{X}_{32}$ & 0.022 & 1 & 0.022 & 0.37 & 0.5568 \\
Residual & 0.60 & 10 & 0.060 & - & - \\
Lack of fit & 0.46 & 5 & 0.092 & 2.80 & 0.1414 \\
Pure of Error & 0.12 & 5 & 0.024 & - & - \\
Cor Total & 14.69 & 19 & & - & - \\
\hline $\mathrm{X}_{1-}$ Time, $\mathrm{X}_{2}$-Temperature, $\mathrm{X}_{3}-\mathrm{pH}$ & & & &
\end{tabular}

The following polynomial given by the Surface model is the relationship between the variable and Pectin yield

$$
\begin{aligned}
\mathrm{Y}(\%)= & +2.39259-0.23342 * \mathrm{X}_{1}+8.69602 \mathrm{E}-003^{*} \mathrm{X}_{2}-0.020847^{*} \mathrm{X}_{3}+0.025463^{*} \mathrm{X}_{1} \mathrm{X}_{2}-0.084269 * \mathrm{X}_{1} \mathrm{X}_{3} \\
& +0.015559^{*} \mathrm{X}_{2} \mathrm{X}_{3}-0.28894^{*} \mathrm{X}_{1}^{2}-5.52657 \mathrm{E}-004^{*} \mathrm{X}_{2}^{2}-0.066593^{*} \mathrm{X}_{3}^{2}
\end{aligned}
$$

Where $\mathrm{Y}=$ pectin yield, $\mathrm{X}_{1}=$ time, $\mathrm{X}_{2}=$ temperature, $\mathrm{X}_{3}=\mathrm{pH}$. This equation shows the effects of the individual variables and their parameters ( $\mathrm{pH}$, time, temperature). Therefore, the results show that these parameters affect the pectin yield. ANOVA for 
Response surface quadratic Model for the pectin illustrated that the model is significant with its F value i.e., 25.99. There are only $0.01 \%$ chances that a "Model F Value" this large could occur due to noise. Values of "Prob $>F$ " less than 0.0500 indicate model are significant. The "Lack of fit" value of 2.80 implies the Lack of fit is not significant relative to the pure error. An insignificant Lack of fit indicates a good fit of the model. The predicted R squared of 0.9221 is closed to Adj R squared i.e., 0.9590 as expected in normal conditions. A ratio greater than 4 is desirable and my ratio is 14.295 indicates an adequate signal. The experimental response for banana peel pectin are given in Table 3 :

Table 3. Design tests of various parameters set by RSM and the responses obtained

\begin{tabular}{lllll}
\hline Run & Factor $1:$ & Factor $2:$ & Factor 3: $\mathrm{PH} \mathrm{X}_{3}$ & Response Yield (\%) \\
& Time(hour) $\mathrm{X}_{1}$ & Temperature $\left({ }^{\circ} \mathrm{c}\right) \mathrm{X}_{2}$ & & 15.87 \\
\hline 1 & 0 & 0 & 0 & 22.32 \\
2 & 0 & +1 & 0 & 21.43 \\
3 & 0 & +1 & 0 & 9.28 \\
4 & -1 & -1 & -1 & 14.28 \\
5 & 0 & 0 & 0 & 16.08 \\
6 & -1 & +1 & +1 & 9.08 \\
7 & 0 & 0 & $-\alpha$ & 5.26 \\
8 & -1 & +1 & -1 & 17.82 \\
9 & 0 & 0 & 0 & 20 \\
10 & 0 & $+\alpha$ & 0 & 12.52 \\
11 & +1 & +1 & -1 & 7.09 \\
12 & +1 & -1 & +1 & 22.43 \\
13 & 0 & +1 & 0 & 17.82 \\
14 & -1 & -1 & +1 & 9.18 \\
15 & 0 & $-\alpha$ & 0 & 19.65 \\
16 & 0 & 0 & 0 & 5.98 \\
17 & $+\alpha$ & 0 & 0 & 23.43 \\
18 & 0 & +1 & 0 & 21.49 \\
19 & 0 & +1 & 0 & 5.69 \\
20 & +1 & -1 & -1 & \\
\hline
\end{tabular}

$\mathrm{X}_{1}$ represents Time, $\mathrm{X}_{2}$ representsTemperature, $\mathrm{X}_{3}$ represents $\mathrm{pH}$

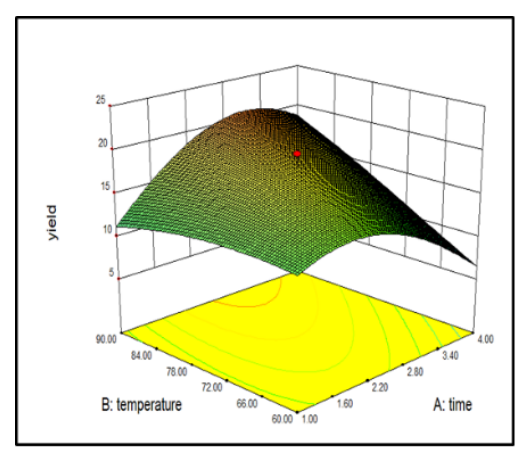

(a)

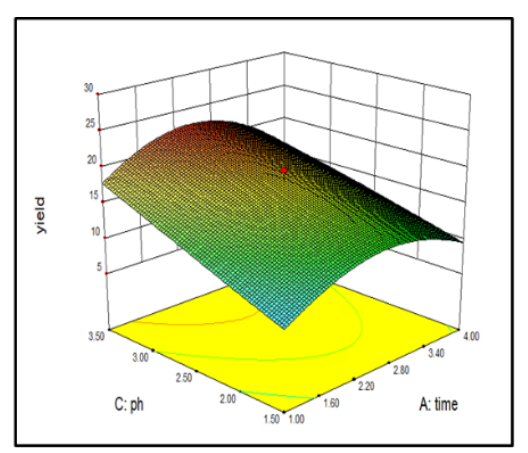

(b)

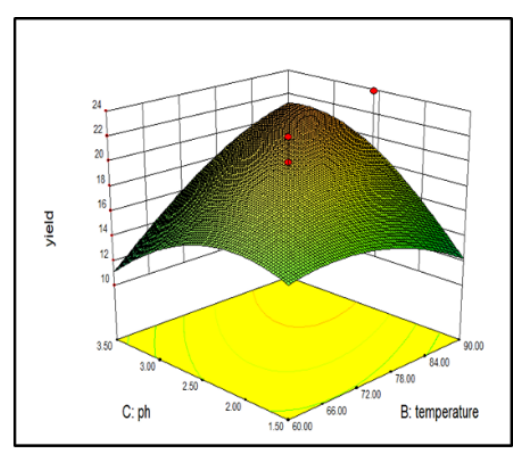

(c)

Fig 2. (a) Effect of temperature and time at constant $\mathrm{pH}$, (b) Effect of time and $\mathrm{pH}$ at a constant temperature, (c) Effect of temperature and $\mathrm{pH}$ at constant time

\subsection{Characterization of pectin}

The physicochemical properties of banana peel pectin dependent on the source and extraction method ${ }^{(8)}$. Extraction of pectin under optimum condition $\left(90^{\circ} \mathrm{C}, 150 \mathrm{~min}, \mathrm{pH} 2.5\right)$ was carried out further for characterization of pectin. Results of characterization of pectin are given in Table 4 : 
Table 4. Results of determination of physicochemical Properties of pectin extracted from banana peels under optimal conditions $\left(90^{\circ} \mathrm{C}, 150\right.$ minutes and $2.5 \mathrm{pH})$

\begin{tabular}{l}
\hline CHARACTERISATION PECTIN \\
\hline Moisture content $12.42 \%$ \\
Ash content $4.57 \%$ \\
Total anhydrouronic acid $31.68 \%$ \\
Methoxyl content $9.3 \%$ \\
Degree of esterification $62 \%$ \\
Equivalent weight $1428.57 \mathrm{~g} / \mathrm{ml}$ \\
\hline
\end{tabular}

\subsubsection{Moisture content}

The moisture content of pectin was found to be between 10-12\%. Hence low moisture content increases the shelf life of pectin and prevents it from microbial degradation ${ }^{(16)}$. Pectin is hygroscopic so it should be stored in an airtight sealed glass container while the previous study by Castillo Isarael has found moisture content between 10-14\%.

\subsubsection{Ash content}

Ash content is the criteria that define the purity of pectin. The purity of the pectin is inversely dependent on Ash content i.e., the pectin with lower Ash content is high in purity. The ash content obtained from pectin was $4-5 \%$. Good quality pectin contains ash content between $9-10 \%$ for gel formation ${ }^{(17)}$

\subsubsection{Methoxyl content}

The methoxyl content obtained with pectin was $8 \%$. According to ${ }^{(6)}$, the banana peel contains high levels of methoxyl content. The methoxyl content of pectin generally ranges from 0.2 to $13 \%$ based on the extraction method and source ${ }^{(18)}$. Commercial pectin methoxyl content is generally diverse at $8-11 \%$ and forms high sugar gels, while low methoxy pectin is diverse at 3-7\% and forms low sugar gels. Also, the methoxyl content affects the dispersibility of pectin, with higher methoxy pectin dispersing more in water than the less than methoxyl content below $70 \%$

\subsubsection{Total Anhydrouronic Acid}

Anhydrouronic acid is also considered to be an important factor for calculating the purity of pectin and the degree of esterification. According to my research, the total anhydrouronic acid being pectin was $31.68 \%$. According to Norazelina, when the AUA content is less than $65 \%$, it shows the presence of impurities such as protein, starch, and sugar. The pectin of immature banana peel is becoming less pure compared to commercial pectin.

Phaviphu Khamsucharit ${ }^{(3)}$ found that $82.05 \%$ and $76.08 \%$ of the AUA\% of citrus peel and apple residue are of high purity, respectively. Another study by ${ }^{(19)}$ found that the \% AUA present in saba banana was 40.0-69.1\%, but Kluai Nam Wa variety of banana found that only more than $65 \%$ AUA\% met the requirements of commercially used pectin ${ }^{(20)}$

\subsubsection{Degree of Esterification}

Gelling properties of pectin are determined by their degree of esterification and lies in the range of 60 to $90 \%{ }^{(21)}$ In previous studies, it was reported that the degree of esterification is affected by temperature ${ }^{(22)}$. Depending on the degree of proportion, pectin can be divided into two parts-rapid settings (DE > 72\%), slow setting (DE,58-65\%) ${ }^{(23)}$

\subsubsection{Equivalent Weight}

This is an important parameter of high molecular weight pectin; high equivalent weight could occur as a consequence of higher partial degradation of pectin ${ }^{(24)}$.Thus, unripe banana has a high equivalent weight as compared to ripe. The equivalent weight of pectin was found at $1428.57 \mathrm{~g} / \mathrm{ml}$ in a banana peel.

\section{Conclusion}

Pectin was successfully isolated from the unripe banana peel with $\mathrm{HCl}$. The optimum condition of pectin was found $2.5 \mathrm{pH}$, temperature $90^{\circ} \mathrm{C}$, and time 2.5 hours to obtain a higher yield. The yield of pectin was between $20-24 \%$. Pectin yields are generally dependent on the source and extraction method. Pectin was successfully isolated from the unripe banana peel with 
$\mathrm{HCl}$. Based on the optimum condition of pectin its characterization takes place. Further increases in time, temperature, and $\mathrm{pH}$ resulted in the degradation of pectin. Thus, pectin extracted from the banana peel in this study could be of higher quality. This study revealed that Response Surface Methodology was an effective software for the optimization of pectin. The statistical analysis indicates that time, temperature, and $\mathrm{pH}$ affect the yield of pectin significantly, and also it concluded that banana peel is a good source of pectin that can be commercially used in food industries and the pharmaceutical industry. Finally, it concluded that the industries that utilize the banana peel for pectin extraction could not only resolve the waste disposal and pollution problem but also it saves foreign exchange imports of pectin. In this regard, the current research going on towards the development of edible film/coatings from pectin. Based on this research two distinctive future directions are found i) The costeffective and efficient methods used to extract pectin, ii) the Extraction of other potential substances by utilizing the by-product of the banana.

\section{Limitations}

- The limitation of this study is that pectin can be extracted in controlled temperature.

- Increase in temperature leads to degradation of pectin and its yield.

- More characterisation of pectin, should be evaluated in future.

- other sources of pectin and its characterisation should be done.

\section{References}

1) Jackson T, Badrie N. Utilisation of banana (Musa acuminata) peel in wine produced in the Caribbean: Effects on physicochemical, microbiological and sensory quality of wines. Journal of food science and Technology. 2003;40(2):153-156. Available from: https://pascal-francis.inist.fr/vibad/index.php? action $=15184074$.

2) Schieber F, Carle SR. By-products of plant food processing as a source of functional compounds-Recent developments. Trends in Food Science and Technology. 2001;12(11):401-413. Available from: https://doi.org/10.1016/S0924-2244(02)00012-2.

3) Khamsucharit P, Haphatanalert KL, Gavinlertvatana P. Klanarong Sriroth and kunruedee Sangseethong.Characterisation of pectin extracted from banana peels of different varieties. Food Science and Biotechnology. 2018;27(3):623-629. Available from: https://doi.org/10.1007/s10068-017-0302-0.

4) Kamble PB, Gowanda S. Extraction of pectin from the unripe banana peel. International Research Journal of Engineering and Technology. 2017;4(7):22592264. Available from: https://www.musalit.org- 17128.

5) Konish YTT, Fukutta M, Tako M. Isolation and structural characterisation of pectin from endocarp of citrus depressa. Food Chemistry. 2007;107(1):352361. Available from: 10.1016/j.foodchem.2007.08.027.

6) Girma E, Worku T. Extraction and Characterisation of pectin from selected fruit peel waste. International Journal of Scientific and Research Publications. 2016;6:447-454. Available from: http://www.ijsrp.org/research-paper-0216.php-P505133.

7) Mesbani G, Jalaljamalian A, Farahnaky. A comparative study on functional properties of beet and citrus pectins in food systems. Food Hydrocolloids. 2005;19(4):731-738.

8) Fissure, Eliana N, Nora M, Ponce, Eva A, Wider, et al. Commercial cell wall hydrolytic enzymes for producing pectin-enriched products from bitternut (Cucurbita moschata, Duchesne ex Poiret). Journal of Food Engineering. 2009;93:293-301.

9) Castillo-Israel KAT, Baguio SF, Diasanta MDB, Lizardo RCM, Dizon EI, Mejico MIF. Extraction and characterization of pectin from Saba banana [Musa 'saba'Musa acuminata x Musa balbisiana] peel wastes: A preliminary study. International Food Research Journal. 2015;22:202-207.

10) Ranganna S. Handbook of analysis and quality control for fruit and vegetable products. New Delhi. Tata Mc Graw-Hill Publishing Company. 1986. Available from: https://www.worldcat.org/itle/handbook-of-analysis-and-quality-control-for-fruits-and-vegeteble-products/oclc/692163756.

11) Devi WE, Shukla RN, Abraham A, Jarpula S, Kaushik U. Optimized Extraction Condition and Characterization of Pectin from Orange Peel". International Journal of Research in Engineering \& Advanced Technology. 2014;2(2).

12) Yapo BM, Robert C, Etienne I, Wathelet B, Paquot M. Effect of extraction conditions on the yield,purity and surface properties of sugar beet pulp pectin extracts. Food chemistry. 2007;100:1356-1364. Available from: https://doi.org/10.1016/j.foodchem.2005.12.012.

13) Kumar S, Sravan. 2015. Available from: https://dx.doi.org/10.4172/2157-7110.1000514.

14) Emaga T, HerinavalonaAndrianaivo R, BernardWathelet, TchangoTchango J, MichelPaquot. Effect of the stage of maturation and varieties on the chemical composition of banana and plantain peels. Food Chemistry. 2007;103(2):590-600. Available from: https://doi.org/10.1016/j.foodchem.2006.09.006.

15) Lin CB, Cze CY. Drying kinetics and optimization of pectin Extraction from banana peels via Response Surface Methodology. Web of conferences. 2018;152:1-14. Available from: https://doi.org/10.1051/matecconf/201815201002.

16) Muhmadzadeh J, Sadeghi-Mahoonak AR, Yaghbani M, Aalami M. Extraction of pectin from sunflower head residues of selected Iranian cultivars. World Applied Sciences Journal. 2010;8:21-24. Available from: https://www.cabdirect.org/cabdirect/abstract/20103090618.

17) Ismail NSM, Ramli N, Hani NM, Meon Z. Extraction and characterization of pectin from dragonfruit (Hylocereuspolyrrhizus) using various extraction conditions. Sains Malaysiana. 2011;41(1):41-45. Available from: https://inis.iaea.org/search/searchsinglerecord.aspx? recordsFor=SingleRecord\&RN= 46134839 .

18) Aina VO, Barau MM, Mamman OA, Zakari A, Haruna H, Umar MSH, et al. Extraction and characterization of pectin from peels of lemon (Citrus limon), grapefruit (Citrus paradise) and sweet orange (Citrus sinensis). British Journal of Pharmacology. 2012;3(6):259-262. Available from: https: //maxwellsci.com/print/bjpt/v3-259-262.pdf.

19) Emaga TH, Ronkart SN, ChristelleRobert, BernardWathelet, MichelPaquot. Characterization of pectins extracted from banana peels (Musa AAA) under different conditions using an experimental design. Journal of food chemistry. 2008;108(2):463-471. Available from: https://doi.org/10.1016/j.foodchem. 2007.10.078. 
20) Kraithong S, Issara U. A strategic review on plant by-product from banana harvesting: A potentially bio-based ingredient for approaching novel food and agro-industry sustainability. Journal of the Saudi Society of Agricultural Sciences. 2021. Available from: 10.1016/j.jssas.2021.06.004.

21) Dom ZM, Mujianto L, Azhar A, Masaudin S, Samsudin R. Physicochemical properties of banana peel powder in functional food products. Food Research. 2021;5(S1):209-215. Available from: 10.26656/fr.2017.5(s1).037.

22) Huang X, Li D, jun Wang L. Characterization of pectin extracted from sugar beet pulp under different drying conditions. Journal of Food Engineering. 2017;211:1-6. Available from: https://doi.org/10.1016/j.jfoodeng.2017.04.022.

23) Makebe CW, Desobgo ZS, Ambindei WA, Billu A, Nso EJ, Nisha P. Optimization of pectinase-assisted extraction of Annona muricata L. juice and the effect of liquefaction on its pectin structure. Journal of the Science of Food and Agriculture. 2020;100(15):5487-5497.

24) Taweechat C, Wongsooka T, Rawdkuen S. Properties of Banana (Cavendish spp.) Starch Film Incorporated with Banana Peel Extract and Its Application. Molecules. 1406;26. 